\title{
Designing E-Commerce Applications for Learning Products in University
}

\author{
Karmila Suryani ${ }^{1, *}$, Rini Widyastuti², Ashabul Khairi³, Muhammad Nurul ${ }^{4}$
}

1,2,3,4Education in Informatics and Computer Engineering Bung Hatta University, Padang, Indonesia

\begin{tabular}{l} 
Article Information \\
\hline Article History: \\
Accepted by the Editor: May 23, 2021 \\
Final Revision: June 11, 2021 \\
Published Online: June 30, 2021 \\
Keywords \\
\hline e-commerce \\
waterfall model \\
marketing \\
Correspondence
\end{tabular}

E-mail: karmila.suryani@bunghatta.ac.id*

\begin{abstract}
A B S T R A C T
E-commerce applications to sell various products produced by students in higher education can increase income-generating. However, a few universities still use e-commerce to sell student products, especially learning products. This research aims to produce an e-commerce application for web-based learning products in universities. The research method is development research with a research design using the waterfall model. The waterfall model procedure consists of analysis, design, coding, and testing. The system design uses Unified Modeling Language (UML) modeling such as context diagrams, class diagrams, use case diagrams, and activity diagrams. The system's coding uses the PHP programming language, Jquery, and the Boostrap Framework. The testing stage is through black-box analysis carried out by experts in the field of system design, with the results of testing each case being well-integrated and feasible to be applied. The result of the research is a web-based e-commerce application that sells learning products in universities.
\end{abstract}

This is an open access article under the CC-BY-SA license

\section{Introduction}

The rapid development of technology impacts all aspects of human life, one of which is the business sector. The business sector most affected by this technological development is trade. Commerce today no longer requires sellers and buyers to deal directly with the transaction. However, all trading transaction activities can be done anytime and anywhere with internet technology. Trade by utilizing internet technology is better known as e-commerce.

The e-commerce business has the opportunity to develop the economy in Indonesia. With more than 250 million people, Indonesia should become a digital economy business player in the world. Internet users in Indonesia continue to increase every year in 2018, which initially amounted to 171.11 million to 254.12 million people [1]. E-commerce is a business whose processes use communication and computer networks [2]. In Indonesia, e-commerce has increased by $17 \%$ in the last 10 years and reached 26.2 million e-commerce business units. It is predicted that it will continue to grow and the increasing number of business actors in Indonesia [3]. The rapid development of e-commerce can satisfy customers such as 3D product display [4].

Seeing the increasing development of e-commerce, IT graduates, especially those from the Bung Hatta University Informatics and Computer Engineering Education Study Program (PTIK), are required to be active players in the digital industry. Apart from PTIK, graduates from other study programs also have the 
same opportunities. Many Start-Ups today provide a place to become a seller in the world of e-commerce. PTIK Bung Hatta University annually graduates who can complete theses. Graduates' diplomas vary, ranging from designing applications for educational needs, developing learning modules, and developing educational games. PTIK student products have benefits not only for research but also for the world of education in other areas to improve the quality and quality of learning. In fact, in PTIK these products merely complete the degree requirements S1 and are not used for the public. The products are only used in place of students doing research. PTIK student products are only stored as study program documentation and archives. Not a few products produced are not implemented following the design objectives.

PTIK student products should have more benefits for the world of education and students as creators. With e-commerce, products can be distributed and students PTIK advertise to anyone who needs it. On the other hand, e-commerce benefits students as creators and generates income to study programs as facilitators. Therefore, a forum is needed to market students' products. One of them is designing e-commerce. Ecommerce design pays attention to connection speed, and readability for application testing are also important factors for e-commerce [5]. Besides that, there are fundamental differences when testing ecommerce for novice users, such as content, design, ease of use, navigation, and structure [6]. Correspondingly, user testing of applications can be carried out through the user environment, continuous user feedback [7]. The e-commerce model that has been made is mostly focused on user satisfaction and the products displayed [8]. In addition, e-commerce is also mostly referred to as online shopping. Online shopping is an activity of buying goods and services through the internet; buyers can see various types of goods and services purchased via the web or applications by sellers [9]. The online transaction process does not require direct face-to-face communication [10] but can be done directly but in different places through notebooks, computers or mobile phones connected to internet access services. Therefore [11] [12] consumers who make shopping transactions on the internet have to wait for their products to be purchased [13].

\section{Method}

The research method used is the Research \& Development (R\&D) method where this research produces a product [14] with a waterfall development model [15]. The waterfall procedure is carried out as shown in figure 1 below.

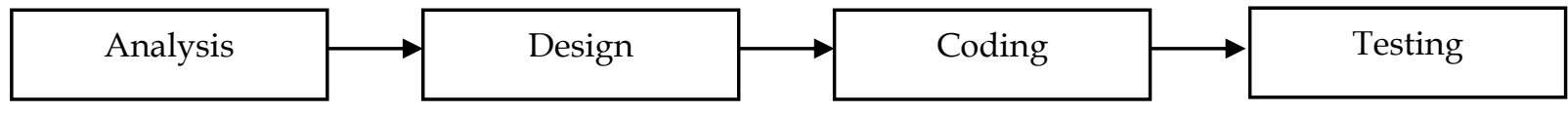

Figure 1. Research Procedure

Figure 1 describes the steps taken to produce e-commerce learning products. The stages of the research are described as follows.

\subsection{Analysis}

An analysis is data needed by the system for good communication to occur to understand the needs and limitations of the software used. The analysis needed is the software and hardware used in producing an ecommerce learning product in higher education.

\subsection{Design}

The design stage aims to translate the requirements of a system into a software design that can be estimated before the program is made. The design process is focused on data structures, interface representations, software architecture and detailed programming procedures. This study uses UML (United Modeling Language) designs such as Context Diagrams, Use Case Diagrams, Class Diagrams and Activity Diagrams. 


\subsection{Coding}

The coding stage is carried out by implementing the design results into program lines. The programming languages used are PHP, HTML, Bootstrap, Javascript, and JQuery . PHP is used to write process orders contained in the application, for example ordering goods and uploading payment receipts. HTML is used to write the basic HTML structure so that php pages can be run on websites. The website that is designed is responsive with the ability to access every device. Javascript and JQuery are used for the ckeditor slider and plugin. Bootstrap is used to give a dynamic look to the website. The coding is also running the program when the program line has been typed on each page. The program can be use by browser such as Google Chrome.

\section{4. $\quad$ Testing}

Testing of applications using black-box testing [15]. This test is a behavioral test that is focused on functional software. Thus the black-box testing technique can be used to assess all cases contained in an application whether it is functioning properly or not.

\section{Results and Discussion}

Based on the needs analysis and file design and database design that has been done, an e-commerce learning product is produced. The design of e-commerce is described into several parts including.

\subsection{Analysis}

The analysis carried out is an analysis of hardware and software requirements. The hardware used in designing this application are: 1) Processor: Intel@ Core TM i3-4030U @ $1.90 \mathrm{GHz}$ CPU, 2) RAM: $2.00 \mathrm{~GB}, 3)$ Hard disk: 500 GB, 4) Standard optical and keyboard, ) Monitor resolution of 1024 x 768 pixels. While the software used is 1) The operating system uses Windows 10 Single Language 64-bit, 2) XAMPP V3.2.2 Web server, 3) MySQL database server, 4) HTML, PHP, JQuery, Javascript, and Boostrap programming languages, 5 )Text editor Sublime Text V3.0 Build 3143 and 6)Google Chrome Internet browser.

\subsection{Design}

Application of e-commerce are designed using a modeling UML (Unified Modeling Language ). The diagrams used are context, class, use case, and activity diagrams.

\subsubsection{Context Diagram}

Context diagrams describe globally the roles of each actor involved in the system and the processes that occur. Context diagram like figure 2.

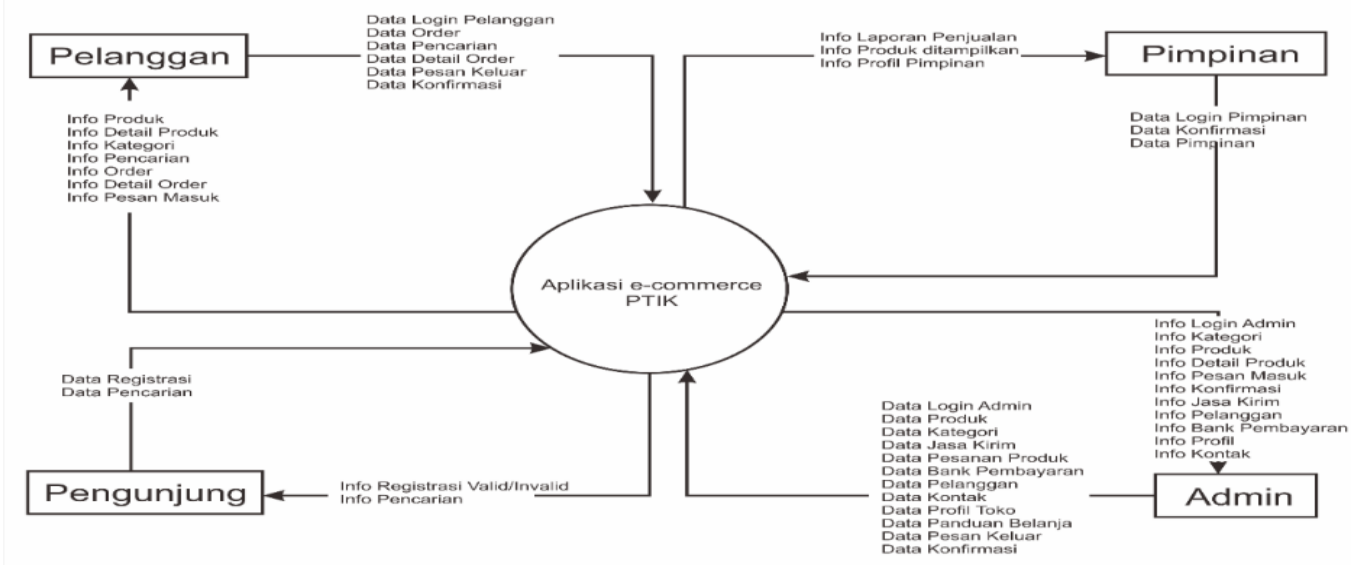

Figure 2. Context Diagram of E-Commerce

Figure 2 is an activity carried out by each existing actor, namely leaders, admins, customers, and visitors. 
Each actor has a right of access are different, the right of access is highest in admin actor. The admin authority manages products, categories, member, and order confirmations. However, products displayed on visitor or customer pages must receive confirmation from the leadership. The arrows pointing to the application indicate what activities the actor performs on the system, and vice versa.

\subsubsection{Use Case Diagram}

The use case diagram for an e-commerce application looks like figure 3.

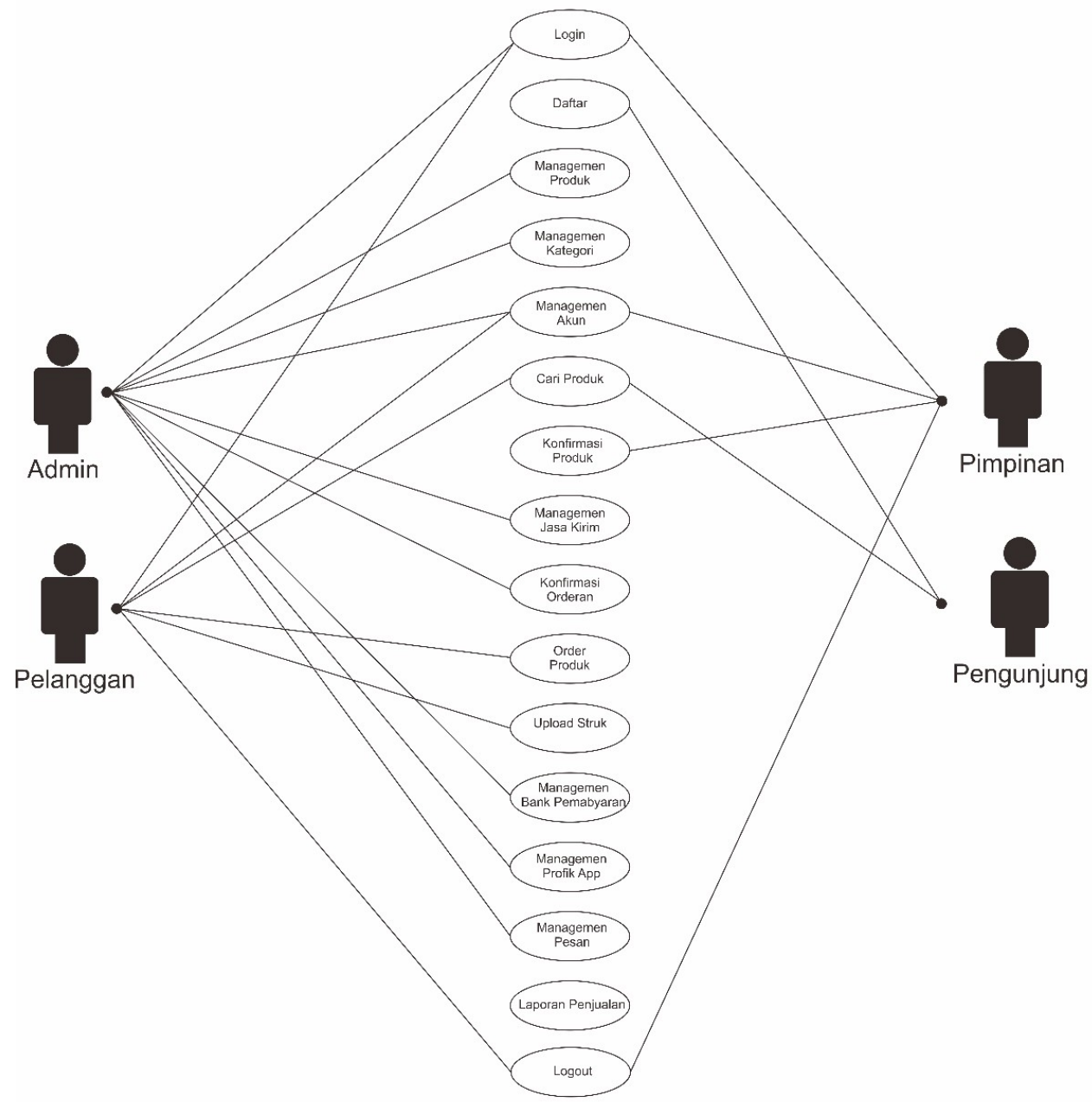

Figure 3. Use Case Diagram of E-Commerce

Figure 3 shows the case for each actor. Actor admin has case login, management products, management categories, management accounts, shipping services, confirmation of orders, payment of bank management, profile management application, message management, and logout. In contrast, the lead actor has the log in case, account management, and product confirmation. Customers are registered on the customer list page, while visitors are application users who can only browse the products being sold and cannot make purchases.

\subsubsection{Class Diagram}

Class diagram is a database contained in e-commerce applications such as figure 4 . 


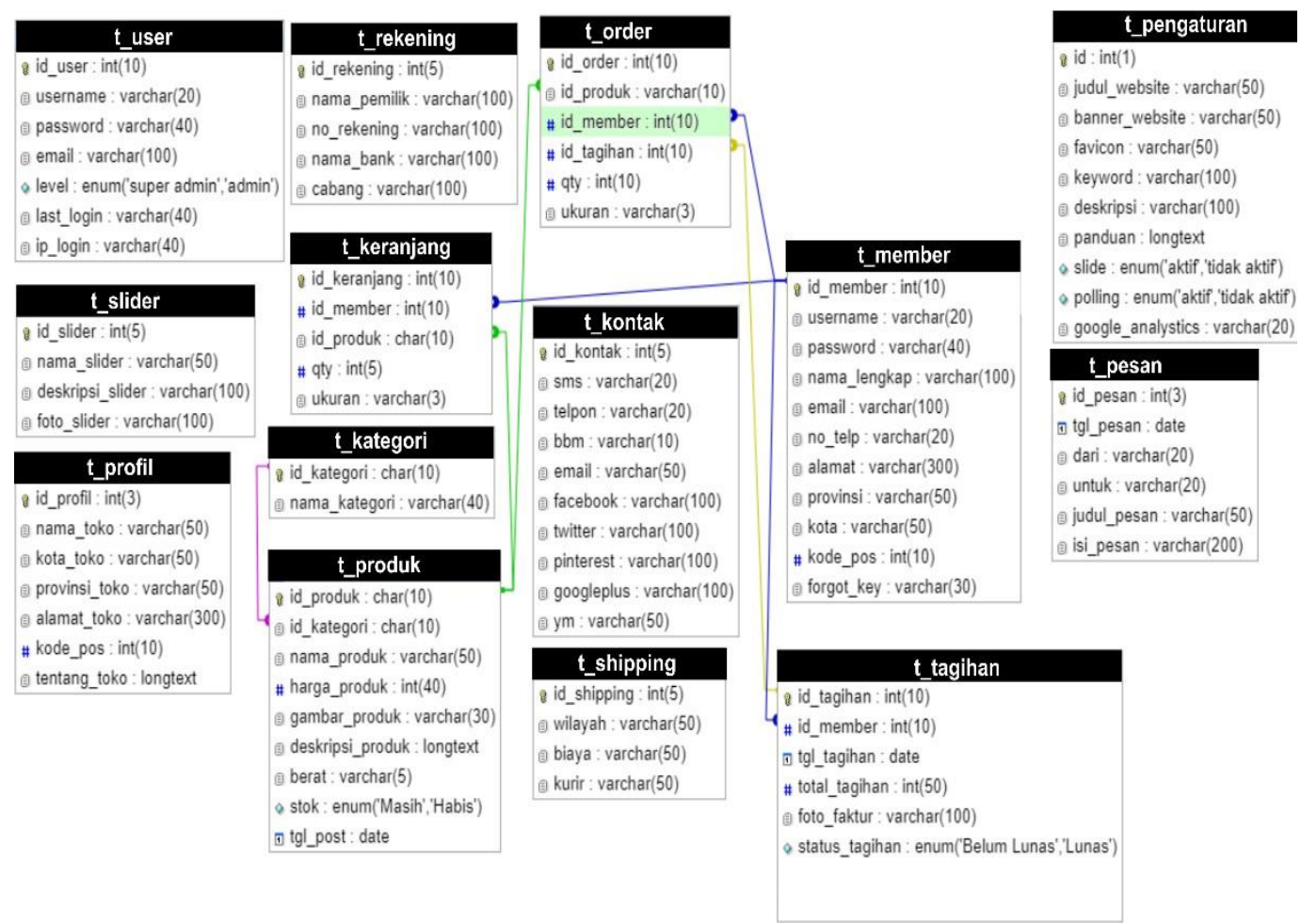

Figure 4. Class Diagram of E-Commerce

Figure 4 provides an overview of the database in an e-commerce application and consists of several interrelated tables. The category table and product table are one-to-many, meaning one category for several products. The member table and billing table are one-to-many, which means that one member account can have several orders and invoices. Likewise with the cart table and the order table, the member table is one to many related.

\subsubsection{Activity Diagram Admin}

The admin diagram illustrates all the activities that can be done by the admin on the application, from managing products and categories to delivery services as shown in figure 5 .

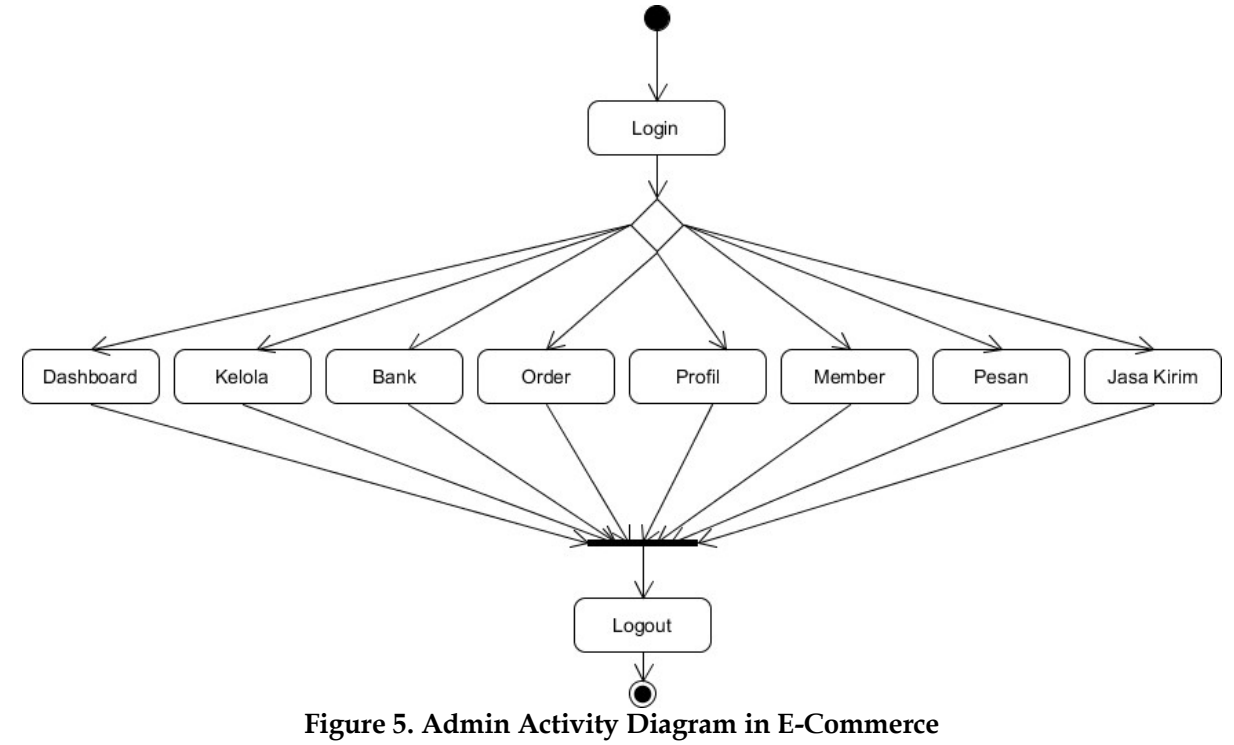

The activity in Figure 5 shows that there are several cases that the admin actor is able to run. Case made 
that corporate governance and product categories. Manage categories authorizes admins to modify, add, and delete categories as needed. Manage products as well, admins can do CRUD (Create, Read, Update, and Delete ). Case bank for payment management.

\subsubsection{Customer Activity Diagram}

Activities that customers can carry out are buying goods and then making payments. Payment receipts are uploaded on the billing menu. Customer activity as figure 6 .

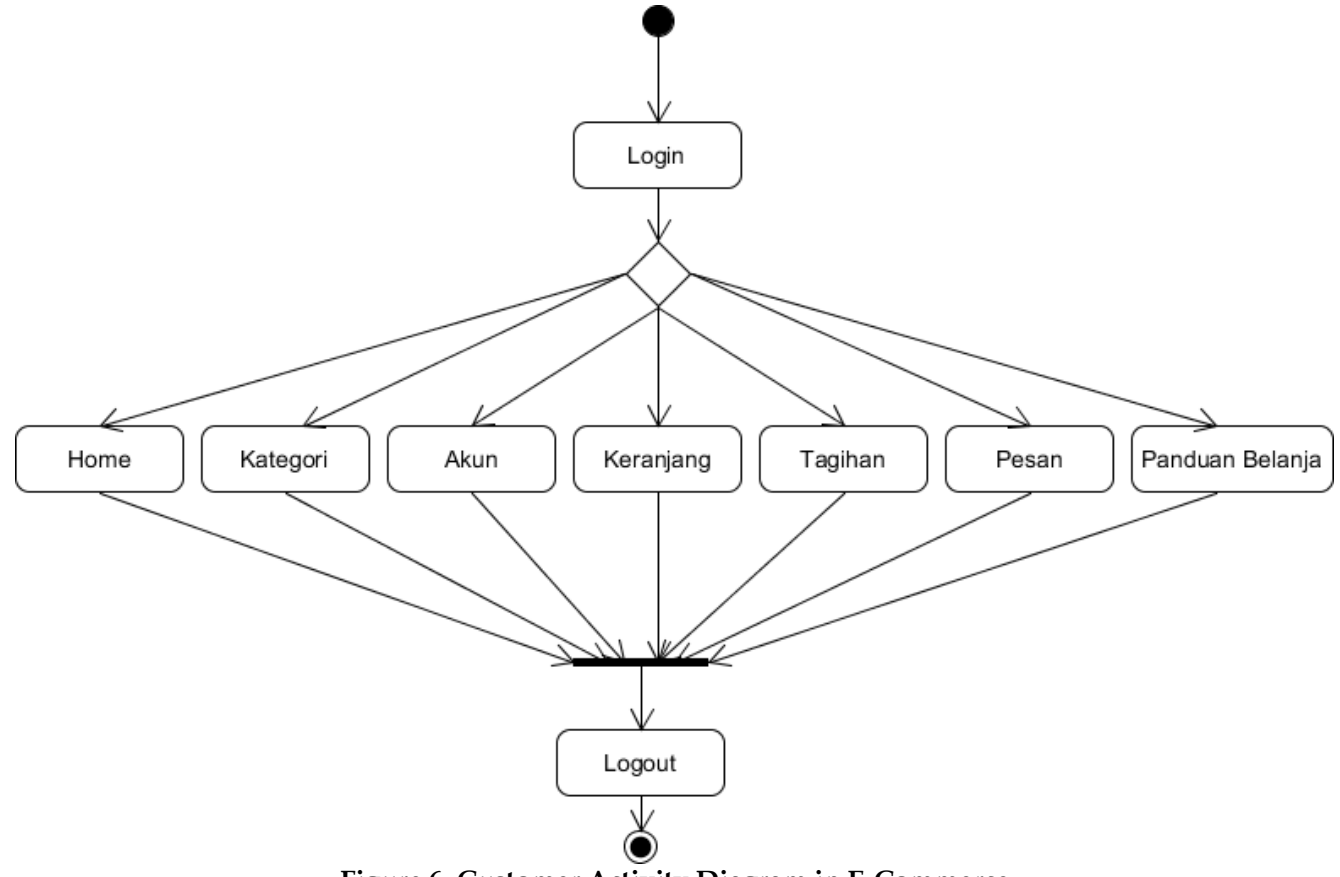

Figure 6. Customer Activity Diagram in E-Commerce

Figure 6 is an activity carried out by customers where before entering, the customer must login first. The first case is the home menu which displays product details and prices. In addition, there are shopping guides and about applications that aim to understand customers using this application. Cart cases provide information to customers about the items that have been selected to be purchased. Customers' case can change the order or delete an existing order. The billing case provides information about the bill amount that the customer must pay. In this case, the customer uploads a payment receipt according to the bill id and bill nominal . The message case works if the customer wants to complain about an order and requests to open a delivery service to the customer's area.

\subsubsection{Leader Activity Diagram}

The leader's activity is to approve all products inputted by the admin to be displayed on e-commerce pages as shown in figure 7 . 


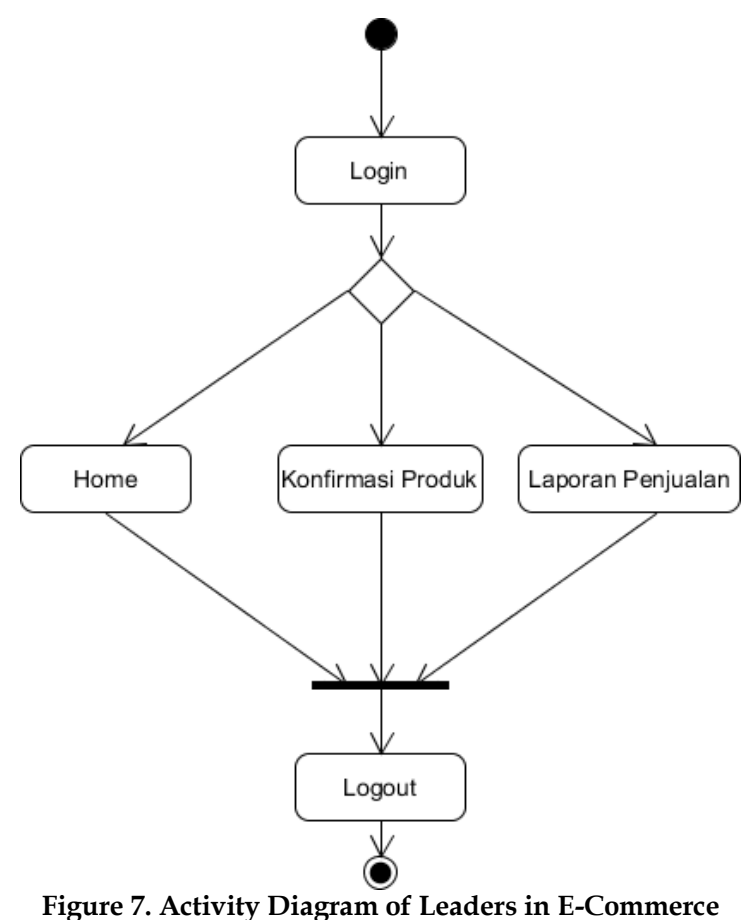

Figure 7 starts using a login with a registered username and password in the application. Leaders have an important role in e-commerce applications, where leaders must permit to appear for every product uploaded by the admin. If the leadership does not approve it, the product is not sold to customers. The next case is the sales report. This report is seen from the number of successful transactions each year.

\subsubsection{Visitor Activity Diagram}

Visitors can see the products sold in this application along with the details of these products. However, visitors must be registered as customers to be able to purchase the products provided as shown in figure 8 .

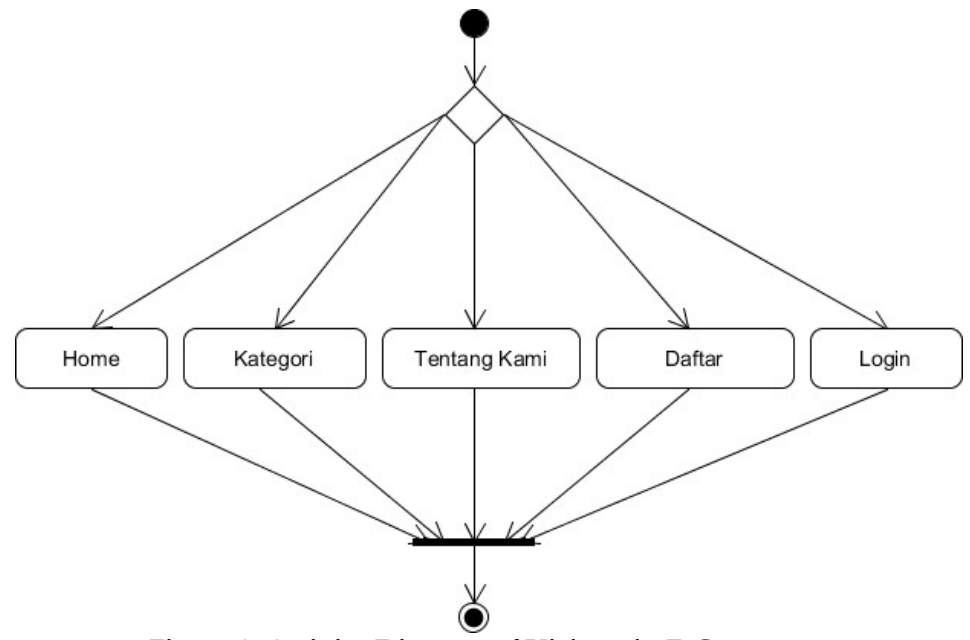

Figure 8. Activity Diagram of Visitors in E-Commerce

Figure 8 is a visitor activity, where visitors can only see the sold products. In order to be able to buy the product that the customer is looking for, they must register in the list case by filling out all the forms provided validly. Visitors are directed to the customer login page if you have successfully registered.

\subsubsection{Admin Page View}

The admin page has the most role in the process of selling this learning product. The menu - a menu that 
is provided to the actor admin ie menu management categories, management of products, order confirmation, customer management, message to the customer, management of shipping services, and the management of the store.

a. Category management

This page serves to manage the categories that are traded in this application. Field - a field it is the id category and the name of the category. This category serves to group products according to product characteristics, besides that, the admin can also manage all existing products as shown in figure 9 .

\section{DAFTAR PRODUK}

\section{DAFTAR KATEGORI}

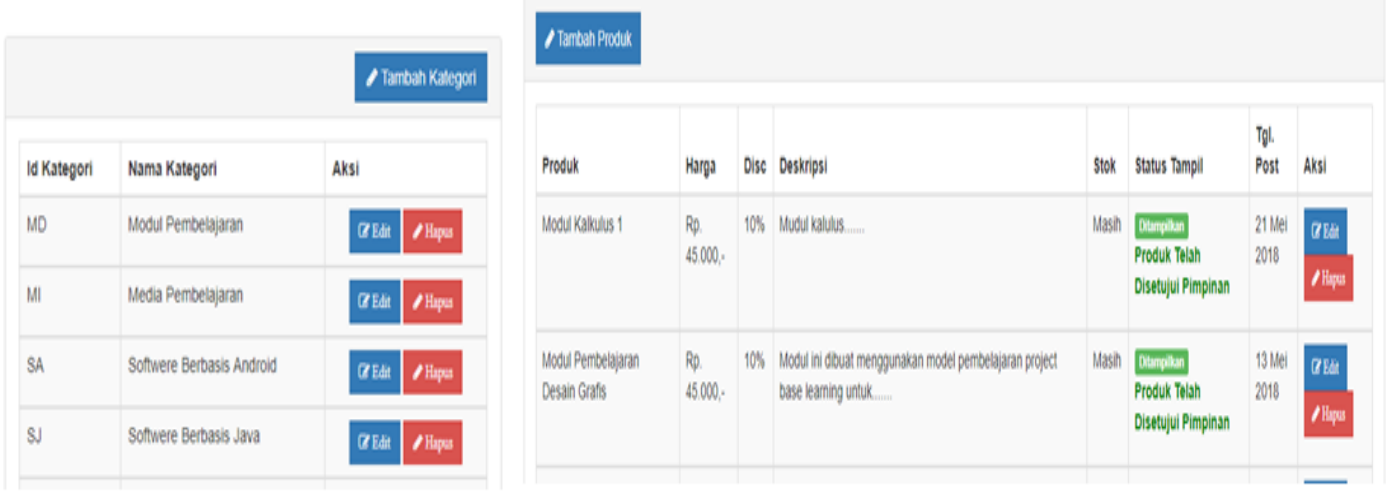

Figure 9. Category Management

Figure 9 describes the admin activities to process the existing categories in e-commerce, for example the products sold are the categories of learning modules, software and so on. Admin can add or remove this product category. Product management is carried out by the admin, especially on product names, prices, product discounts, product descriptions, stock, display status, and product post dates. [16], [17] revealed that the services provided by the admin for various products can make customers become interested in using e-commerce. Therefore, the category management of the products displayed in e-commerce is updated from time to time.

b. Store Mangement

Store management manages the application's appearance starting from the web name, city, web address, and regional POS code as shown in figure 10

DAFTAR JASA KIRIM

\begin{tabular}{|c|c|c|c|c|}
\hline Wilayah & Biaya & Kurir & Aksi & \\
\hline Jakarta Pusat & Rp. 13.000 ,- & PT Pos Indonesia & $\mathbb{Z}$ Edit & Hapus \\
\hline Jakarta Barat & Rp. 13.000 ,- & PT Pos Indonesia & $\mathbb{Z}$ Edit & Hapus \\
\hline Padang & Rp. 15.000 ,- & PT Pos Indonesia & $\mathbb{E}$ Edit & Hapus \\
\hline
\end{tabular}

Figure 10. Shipping Management

Figure 10 is the management of the application of e-commece generated, Field - the field is displayed to the consumer as PtikStore about the information. The PtikStore address, especially the city, is used as a reference for determining the cost of sending goods to customers. All fields can be changed according to the 
actual needs and data. Store management is directly related to customer service satisfaction, [18] has proven that customer satisfaction from an e-commerce is strongly influenced by its appearance.

c. Payment Account Number Management

The payment account management page, set the admin account numbers that customers would use to conduct payment bill expenditures. Admin can delete, add, and change existing account numbers. Field her field is the owner's name, account number, bank name, and branch offices as shown in figure 11.

\begin{tabular}{|l|l|l|l|l|}
\hline \multicolumn{1}{|l|}{ Tambah Rekening } & & & \\
\hline Nama Pemilik & No. Rekening & Nama Bank & Cabang & Aksi \\
\hline Muhammad Nurul & 123456789 & BRI & Jambi & $\mathbb{Z}$ Edit \\
\hline
\end{tabular}

Figure 11. Account Number Management

\section{d. Sales Report}

The e-commerce application is equipped with sales reports. The fields displayed are order no, name, order date, status and total shopping. This report aims to provide information about successful sales and the amount of profit that has been received as shown in figure 12 .

\section{CETAK LAPORAN}

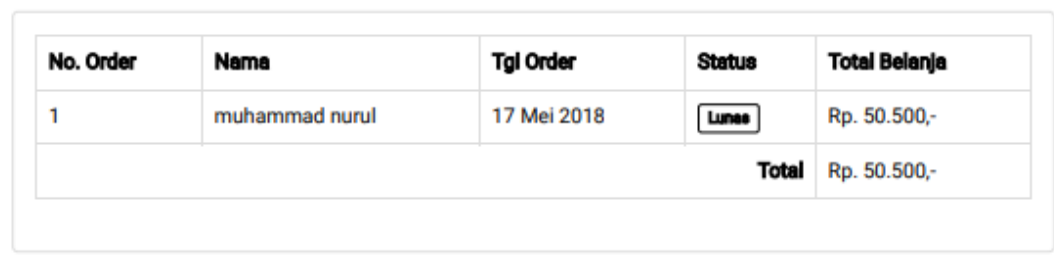

Figure 12. Sales Report

The report shown in figure 12 is in hardcopy form and is used to analyze the advantages and disadvantages that have been received. This report also supports leadership decisions on policies that will be issued for learning products sold.

\subsubsection{Visitor Page View}

Application of e-commerce bring up the menu - a menu such as the home menu, a menu category, product, about the store, the list of customers, login customers. Face to face at the end of this encounter when accessing these applications. Visitors can search for the product they need by clicking the search button at the top of the main page, but visitors can not click the buy button before logging in as an ecommerce application customer as shown in figure 13. 


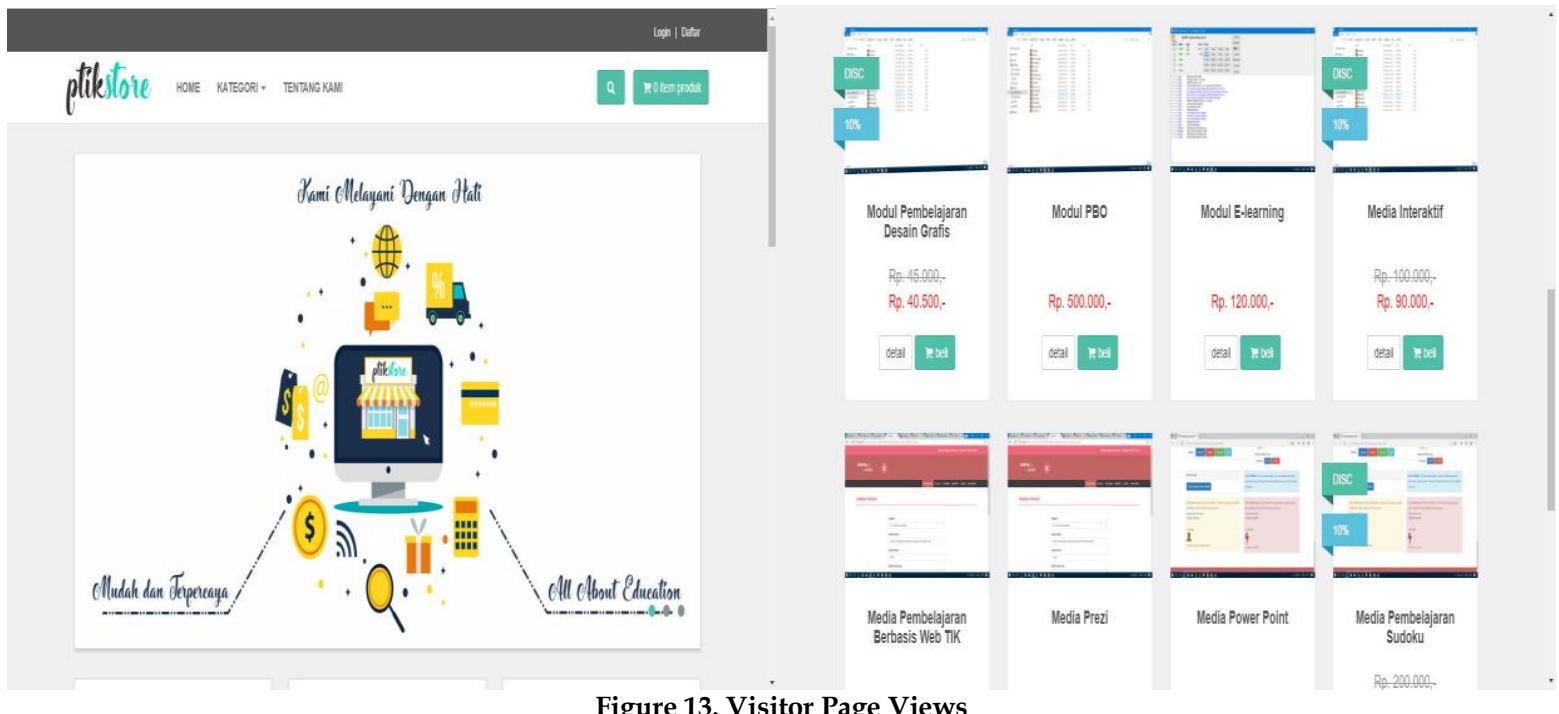

Figure 13. Visitor Page Views

Figure 13 is a yard major that visitors access. On this page there is a slider that aims to provide information about the website. Items sold are displayed in their entirety on the body of the page. The footer of the page contains the website's contact information and social media. Visitors can see all the products contained in the e-commerce application. [19] [20] Visitors to an e-commerce always pay attention to contemporary products, especially in terms of appearance. Therefore, all products whose designs are displayed are always improved and made more attractive.

Application of e-commerce raises a wide range of menus that can be used to purchase the product. The menus include menu login, menu home, menu category, account management, billing menu, message to admin, shops, shopping guides, product search, shopping cart, checkout, upload the receipt of payment, and logout. This customer page looks like figure 14 .
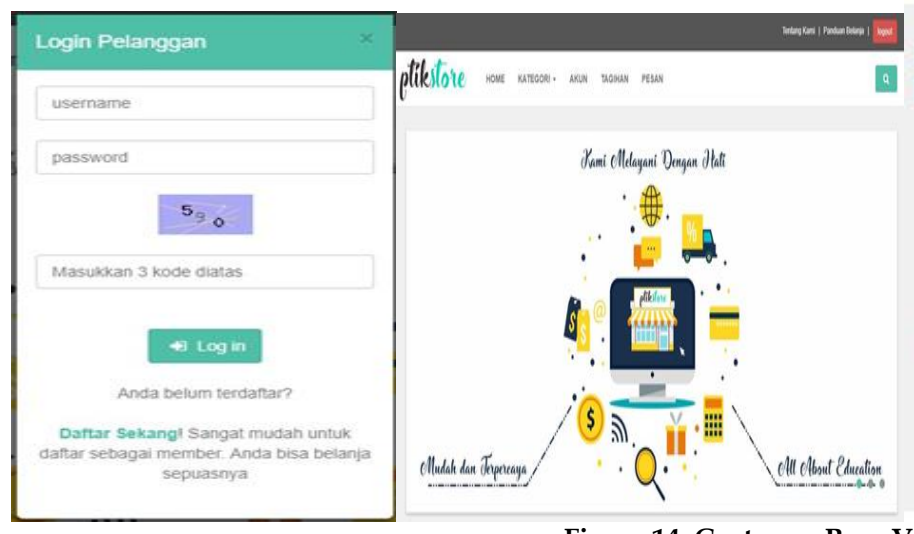

Figure 14. Customer Page View
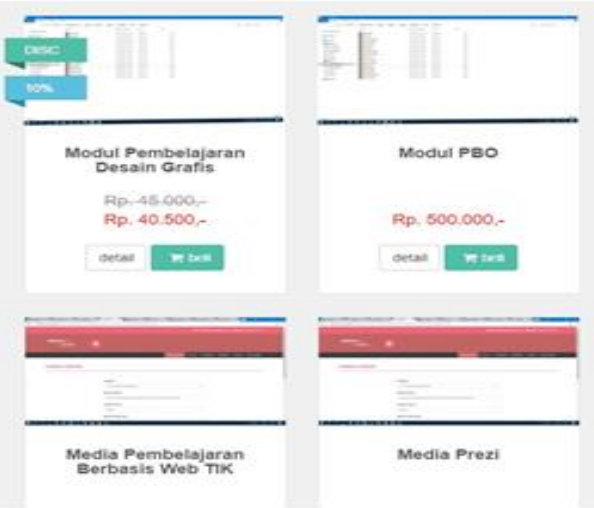

Figure 14 is a facility contained in a customer account. Before making a sales transaction, the customer first logs in. The content displayed is not much different from the main page of visitors; there are only additional menus, such as a shopping guide menu, about us, and a logout button. The detail button and buy the product can already be used on this page. Customers can perform account management such as identity. In addition, customers are also shown to view and delete shopping baskets and are welcome to make payments when the items purchased are following their wishes. The payment process can be done using transfers at various banks provided by the application; even customers can also make payments on the spot [21]. In addition, customers are also facilitated to send messages to admins related to the processes carried out on e-commerce applications. 


\subsubsection{Leader Page View}

Leaders play an important role in the sales flow of learning products in this e-commerce application. This application provides menus for lead actors such as product confirmation and product sales reports. Destination product confirmation page of this menu is to filter the products are sold to consumers. Rights of access is owned by leader of Program Study the notes to the fields of products is only filled by admin, led only confirm the uploaded products to be displayed to the consumer, such as figure 15.

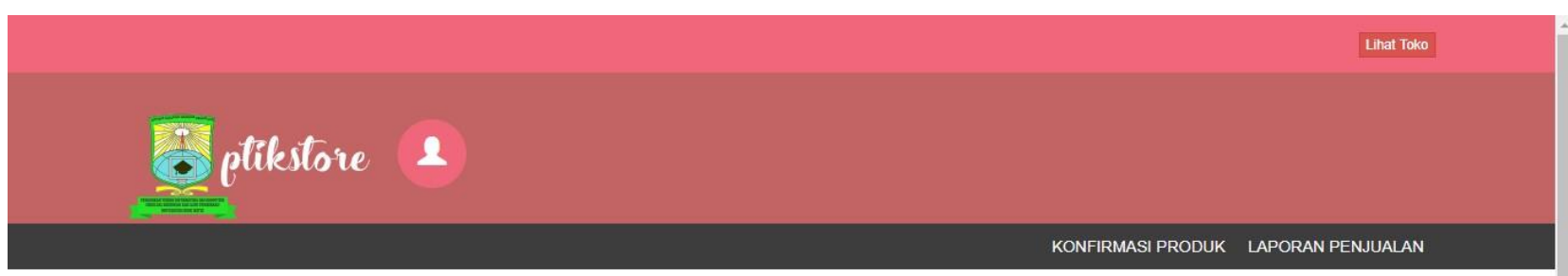

\section{DAFTAR PRODUK}

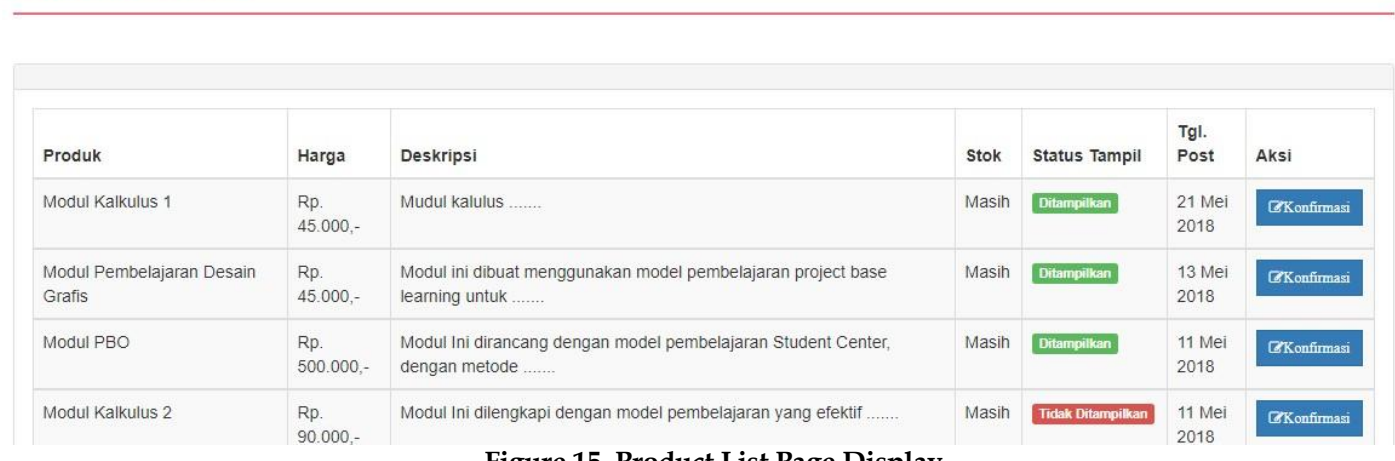

Figure 15. Product List Page Display

\subsection{Coding}

The coding used in the e-commere application uses PHP and the MYSQL database in outline as the following program listing.

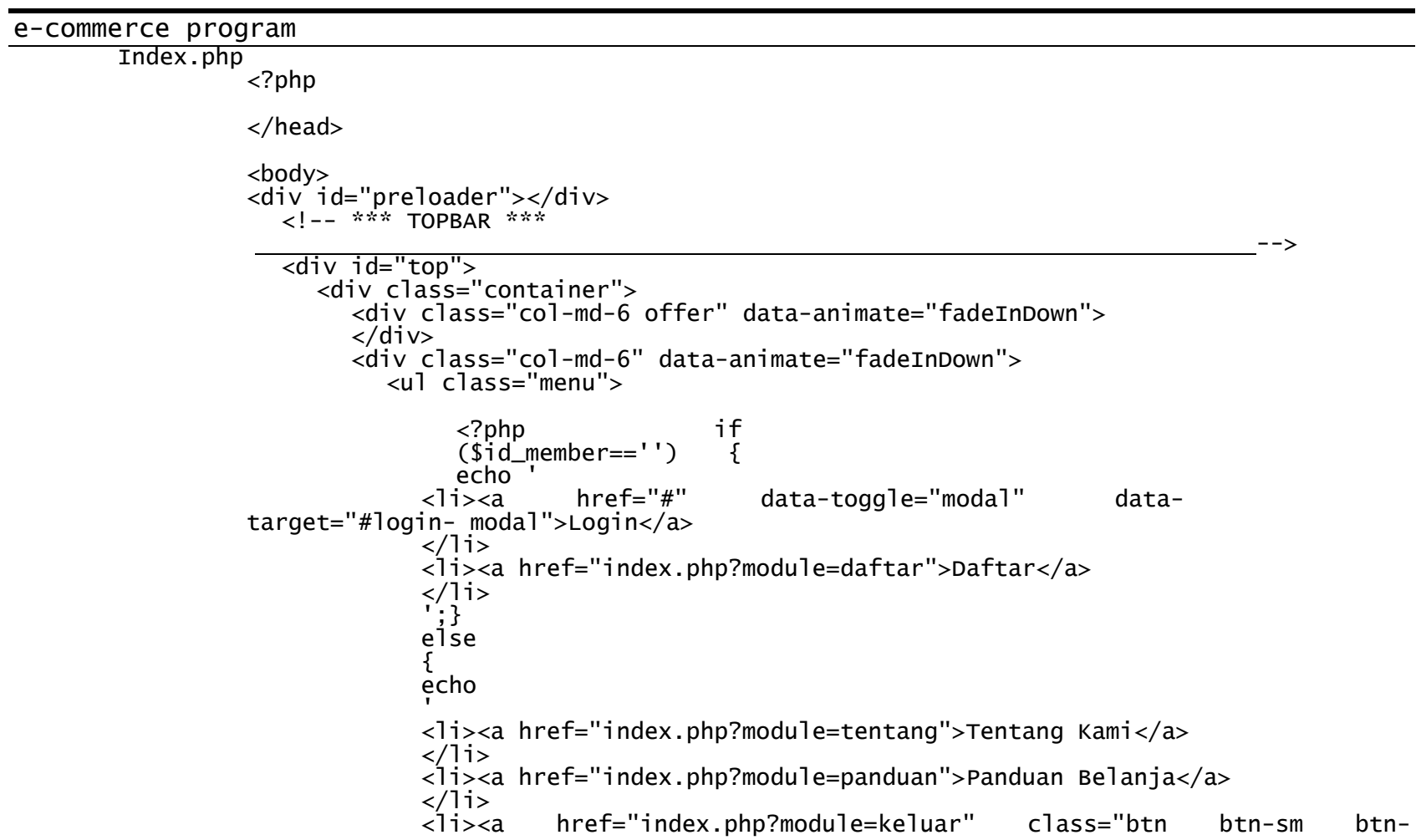




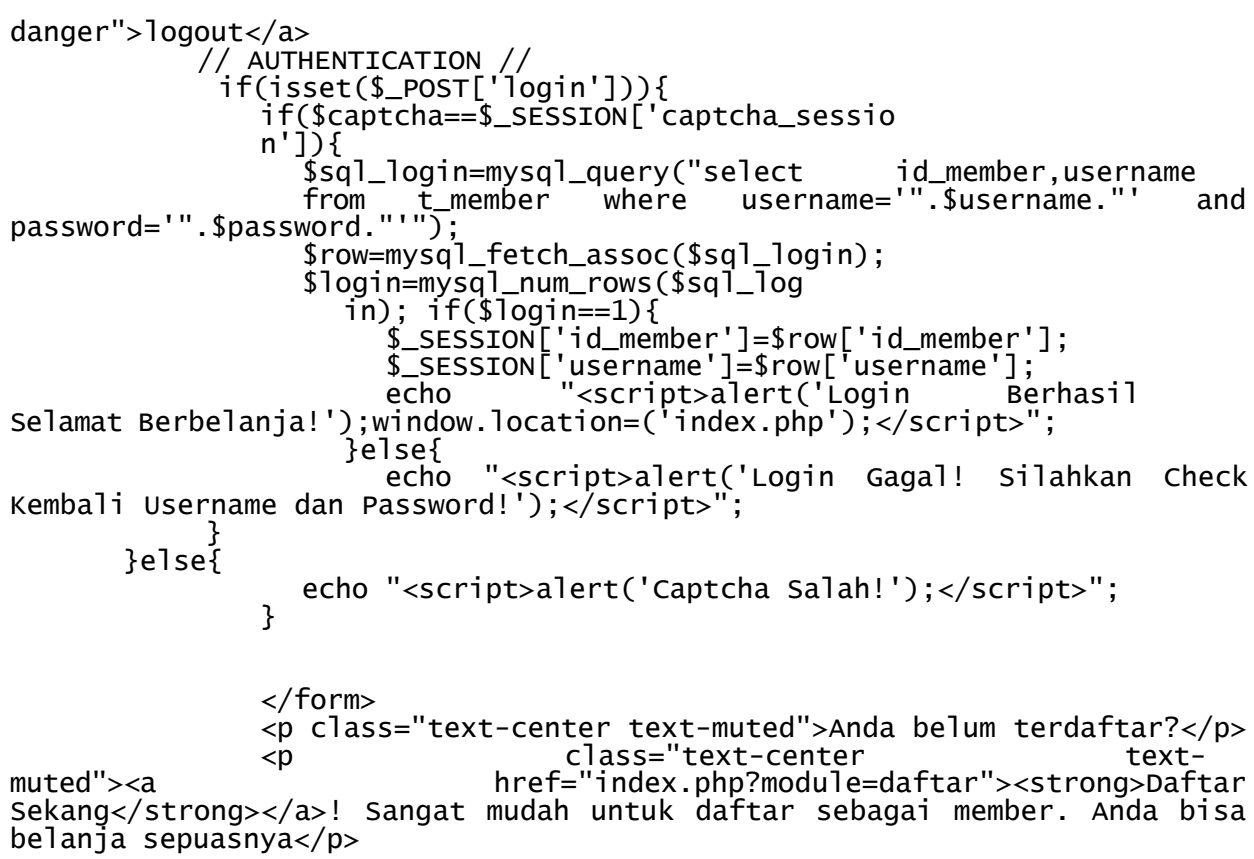

\subsection{Testing}

Tests are carried out on all existing facilities in e-commerce carried out by experts in the software field. The validation results by the validator stated that all cases on each actor went well. The test results using the Black Box as shown in table 1.

Table 1. Test Results

\begin{tabular}{|c|c|c|c|c|c|}
\hline No & Test Case & Test Step & Expected Results & Actual Results & Description \\
\hline 1. & $\begin{array}{l}\text { Admin, Customer } \\
\text { and Leader Login } \\
\text { Menu }\end{array}$ & $\begin{array}{l}\text { Run the program to input } \\
\text { the URL of the website } \\
\text { address, the login menu } \\
\text { immediately appears } \\
\text { (Admin, Customer and } \\
\text { Leader) }\end{array}$ & $\begin{array}{l}\text { Displaying Admin, } \\
\text { Customer and Leader } \\
\text { login forms }\end{array}$ & $\begin{array}{c}\text { Admin, } \\
\text { Customer and } \\
\text { Leader login } \\
\text { page display }\end{array}$ & Succeed \\
\hline 2. & Main page menu & $\begin{array}{l}\text { URL input program } \\
\text { website address }\end{array}$ & $\begin{array}{l}\text { Displays the main } \\
\text { menu }\end{array}$ & $\begin{array}{c}\text { Main menu page } \\
\text { display }\end{array}$ & Succeed \\
\hline 3. & Product menu & $\begin{array}{l}\text { Select the product list } \\
\text { menu }\end{array}$ & $\begin{array}{l}\text { Displays the product } \\
\text { list data form }\end{array}$ & $\begin{array}{l}\text { Product list data } \\
\text { page display }\end{array}$ & Succeed \\
\hline 4. & $\begin{array}{l}\text { Product details } \\
\text { menu }\end{array}$ & $\begin{array}{c}\text { Click the selected } \\
\text { product. }\end{array}$ & $\begin{array}{l}\text { Displaying the } \\
\text { product detail form }\end{array}$ & $\begin{array}{l}\text { Product detail } \\
\text { page view }\end{array}$ & Succeed \\
\hline 5. & Purchase menu & Select the purchase menu & $\begin{array}{l}\text { Displays the purchase } \\
\text { data form }\end{array}$ & $\begin{array}{c}\text { Purchase page } \\
\text { view }\end{array}$ & Succeed \\
\hline 6. & Cart page menu & go to cart page menu & $\begin{array}{l}\text { Display n cart page } \\
\text { form }\end{array}$ & $\begin{array}{l}\text { Cart menu page } \\
\text { view }\end{array}$ & Succeed \\
\hline 7. & Payment page menu & Enter proof of payment & Show payment form & $\begin{array}{c}\text { Displays } \\
\text { payment data. }\end{array}$ & Succeed \\
\hline 8. & Report page menu & $\begin{array}{l}\text { Select the report print } \\
\text { button }\end{array}$ & Show report page & $\begin{array}{l}\text { Displaying pdf } \\
\text { data on the } \\
\text { report page }\end{array}$ & Succeed \\
\hline
\end{tabular}

\section{Conclusion}

Based on the results, it has generated an application of e-commerce product of learning in Higher Education. The E-commerce application has gone through the stages of testing carried out by experts in the 
software field with the results that all cases contained in the application run well. Actors involved in ecommerce applications are admins, visitors, customers and leaders.

\section{References}

[1] F. Mulia and B. M. Sulungbudi, "Pemanfaatan Teknologi Digital Pada UMKM (Studi Penggunaan Internet Pada PPKM Kabupaten Bandung)," vol. 4, no. 2, pp. 1-11, 2020.

[2] A. Burcori, "Pentingnya Literasi Digital Untuk Meningkatkan Partisipasi Masyarakat Dalam Sosialisasi Pembangunan Melalui Media Sosial," OMNICOM J. Ilmu Komun., vol. 4, no. 1, pp. 1-6, 2018.

[3] Y. Irma and L. Suryani, "Perancangan E-Commerce Batik Pada Batik Banten," J. Ilm. Sains Teknol., vol. 1, no. 2, pp. 66-81, 2018.

[4] J. Geelhaar and G. Rausch, "3D Web Applications in E-Commerce - A secondary study on the impact of 3D product presentations created with HTML5 and WebGL," 2015 IEEE/ACIS 14th Int. Conf. Comput. Inf. Sci. ICIS 2015 - Proc., pp. 379-382, 2015.

[5] H. Zheng, "A study on the usability of E-commerce websites between China and Thailand," Int. J. Simul. Syst. Sci. Technol., vol. 17, no. 1, pp. 34.1-34.4, 2016.

[6] S. K. Panda, S. K. Swain, and R. Mall, “An Investigation into Usability Aspects of E-Commerce Websites Using Users ' Preferences," Adv. Comput. Sci. an Int. J., vol. 4, no. 1, pp. 65-73, 2015.

[7] M. C. Anchahua, L. V. Garnique, and J. A. Tarazona, "User Experience Maturity Model for Ecommerce Websites," 2018 Congr. Int. Innov. y Tendencias en Ing. CONIITI 2018 - Proc., pp. 1-6, 2018.

[8] S. D. Axinte and I. C. Bacivarov, "Improving the Quality of Web Applications Through Targeted Usability Enhancements," Proc. 10th Int. Conf. Electron. Comput. Artif. Intell. ECAI 2018, pp. 1-4, 2019.

[9] F. Kawaf and D. Istanbulluoglu, “Online fashion shopping paradox: The role of customer reviews and facebook marketing," J. Retail. Consum. Serv., vol. 48, pp. 144-153, 2019.

[10] S. Sohn, "A contextual perspective on consumers' perceived usefulness: The case of mobile online shopping," J. Retail. Consum. Serv., vol. 38, no. January, pp. 22-33, 2017.

[11] J. Kim, M. Kim, J. Choi, and M. Trivedi, “Offline social interactions and online shopping demand: Does the degree of social interactions matter?," J. Bus. Res., vol. 99, no. September, pp. 373-381, 2019.

[12] A. Ibrahim, S. D. R. Napian, A. Firanisa, Sartika, R. D. Sari, and M. Audya, “The Effect of E-Commerce Application Service Quality of Customer Loyalty Using Customer Relationship Management Approach," vol. 172, no. Siconian 2019, pp. 680-687, 2020.

[13] T. H. Liao, “Online shopping post-payment dissonance: Dissonance reduction strategy using online consumer social experiences," Int. J. Inf. Manage., vol. 37, no. 6, pp. 520-538, 2017.

[14] Sugiyono, Metode Penelitian Kuantitatif, Kualitatif, dan RED. Bandung, 2018.

[15] S. A. S., Rosa, M. Rekayasa Perangkat Lunak Terstruktur Dan Berorientasi Objek, vol. 1. Bandung: Informatika, 2018.

[16] R. Belwal and M. Amireh, "Service quality and attitudinal loyalty: Consumers' perception of two major telecommunication companies in Oman," Arab Econ. Bus. J., vol. 13, no. 2, pp. 197-208, 2018.

[17] S. Kanimozhi, Selvasarathi, Shanmathi, Sneha, "Recommendation System Using Hybrid Classification Algorithm in E-Commerce Application," Turkish J. Physiother. ..., vol. V, no. 2, pp. 2305-2311.

[18] F. F. Cheng, C. S. Wu, and Y. C. Chen, "Creating customer loyalty in online brand communities," Comput. Human Behav., vol. 107, no. 181, p. 105752, 2020.

[19] V. Oktaviani, B. Warsito, H. Yasin, R. Santoso, and Suparti, "Sentiment analysis of e-commerce application in Traveloka data review on Google Play site using Naïve Bayes classifier and association method," J. Phys. Conf. Ser., vol. 1943, no. 1, pp. 1-9, 2021.

[20] J. J Sivasankar, E., \& Vijaya, “A study of feature selection techniques for predicting customer retention in telecommunication sector," Int. J. Bus. Inf. Syst., vol. 31, pp. 1-26, 2019.

[21] T. Wu, X. Liu, J. Qin, and F. Herrera, “An interval type-2 fuzzy Kano-prospect-TOPSIS based QFD model: Application to Chinese e-commerce service design," Appl. Soft Comput., vol. 111, p. 107665, 2021. 